\title{
Ambiances
}

anbiances Environnement sensible, architecture et espace urbain Varia | 2017

\section{In the Clouds: On the Vagueness of Atmospheres}

Dans les nuages: le vague des ambiances

\section{Andreas Rauh}

\section{OpenEdition}

\section{Journals}

\section{Electronic version}

URL: http://journals.openedition.org/ambiances/818

DOI: 10.4000/ambiances.818

ISSN: 2266-839X

\section{Publisher.}

Direction Générale des Patrimoines - DAPA - MCC, UMR 1563 - Ambiances Architectures Urbanités $(\mathrm{AAU})$

\section{Electronic reference}

Andreas Rauh, «In the Clouds: On the Vagueness of Atmospheres », Ambiances [Online], Varia, Online since 08 February 2017, connection on 19 April 2019. URL : http://journals.openedition.org/ ambiances/818; DOI : 10.4000/ambiances.818

This text was automatically generated on 19 April 2019

\section{(c)}

Ambiances is licensed under a Creative Commons Attribution-NonCommercial-NoDerivatives 4.0 International License. 


\title{
In the Clouds: On the Vagueness of Atmospheres
}

\author{
Dans les nuages : le vague des ambiances
}

\section{Andreas Rauh}

1 A single drop does not constitute rain and a single droplet of water vapor does not make a cloud. The cloud itself is a mutable whole, discrete, but without solid, stable boundaries. When one descends into a cloud, one is surrounded by a diffuse nebulousness and finds oneself in a space without corners or edges. It is similar to someone experiencing a certain atmosphere - such as the brassy atmosphere of a Christmas market. This atmosphere is distinct from the gloomy atmosphere of urban backstreets. One can even list the material ingredients that make up the atmosphere of Christmas markets: the warm light radiating from (real wax and electric) candles, the glittering of the opulent display of goods, the warmth emanating from human crowds, the smell of roasted almonds, baked apple, and bratwurst, the taste of mulled wine and sweet baked goods. Yet once one has immersed oneself in the atmosphere of Christmas markets, one finds it hard to match or ascribe the manifold aesthetic impressions to one concrete sensing of atmosphere. The question is, which component of atmosphere is formative, and to what extent? Generally speaking, atmosphere is experienced intrusively as a certain presence of something. This kind of intra-atmospheric infinity has also made the cloud a popular metaphor for the internet and online communities: when data move into the cloud, conventional understandings of space and time become obsolete. Data become diffuse, vague, and cloudy. Like clouds, data networks cover the Earth and add to its atmosphere an electrosphere ${ }^{1}$, allowing the users of virtual worlds to upload their data and identities into the cloud and experience immersion in global information flows. The notion of atmosphere itself is connected to the meteorological metaphor of the cloud (alongside its electronic counterpart), and is known in both ordinary and exceptional contexts. The atmosphere generates both weather and sense phenomena; it surrounds the Earth as well as encompasses our sensual perceptions and influences both the unfolding of weather events and the flow of perception. To be immersed in an aesthetic atmosphere is to be 
involved in affective worlds that color one's own perceptions and steer them in certain directions. That having been said, the very omnipresence of atmosphere implicitly claims a decisive influence on our perception, attitude and action and, in doing so, turns aesthetics as aisthetics into a fundamental discipline of epistemological reflections.

The following paper sets out to explore such atmospheres, to examine what makes them cloudy, and what constitutes their vagueness ${ }^{2}$. It begins with a short definition of atmosphere before clarifying the central problem by examining vagueness in everyday language. The example of the sorites paradox will then be used to demonstrate how vagueness has classically been understood, so that distinct forms of vagueness can be differentiated and their connections to atmosphere, as a phenomenon, can be better shown. In concluding the argument, this clarification will be used to draw attention to some methodological consequences for research into atmospheres.

The cloudy and nebulous aspect of the atmosphere is already indicated in its etymology: the components 'atmos' and 'sphaira' form the image of a 'vaporous sphere' surrounding a planet. Life on Earth is possible only by virtue of its atmosphere, which mediates between the nothingness of space and the 'everythingness' of the world. Carried over into the field of aesthetics, the atmosphere retains this indeterminate, intermediate position. It is the, at first, inconspicuous 'and' in Gernot Böhme's definition which uncovers in atmospheres the "relationship between one's state at a given time and the qualities of one's surroundings. This and, this in-between, that by which the qualities of a setting relate to one's condition, this is the atmosphere" (Böhme, 1995, p. 22-23) 3 . With this 'and', a relationship is determined which could, generally speaking, also describe phenomena like fear, which seems to lie somewhere between a frightened subject and a frightening object. The 'and' of the atmosphere also suggests that the atmosphere is not merely a mediator, but prepares the ground for the mediation; that is, the frightened subject only perceives an object as a frightening one, and is able to personally experience this kind of perception, because of the atmosphere of fear. Thus, the atmosphere of fear should not be understood solely as a subjective projection of an inner mood onto the world outside. The 'and' complicates its precision and the intelligibility; the relation is always and everywhere present to varying degrees of markedness and intensity. According to Herrmann Schmitz's understanding of phenomena, it is perceived as affecting the felt body, as individual feelings floating through space (see e.g., Schmitz, 2014, p. 30). Thus, atmospheres can be defined as precognitive, or at least preverbal, phenomena. Because they feature so prominently in everyday language and 'atmosphere', as a term, is used matter-of-factly, a more thorough engagement with this concept is called for, as it is, in fact, not always clear what precisely is being referred to.

\section{Everyday Language and Vagueness}

4 When discussing the topic of atmosphere, discrepancies are apparently unavoidable. On the one hand, we often understand one another with regard to atmospheres and by means of atmospheres, but on the other hand, it is often impossible to describe a given atmosphere, as one cannot pinpoint what one is feeling, where one is feeling it, and to what degree it is being felt. The notion or concept of atmosphere or atmosphere itself appears vague, nebulous, and ill-defined, a status that seems to deny the possibility of advancing understanding. Of course, the problem of describing an atmosphere depends on its intensity and nature, which can be as powerful as that of a Christmas market, or as 
subtle as the relaxed atmosphere of a quiet afternoon. This problem of description also derives from the vagueness of atmospheres as has already been noted above. This vagueness precedes the relationship between a setting or an environment and one's individual state like an uncertainty constant preceding a formula. No matter how welldefined and well-known the individual components of an 'atmospheric recipe' might be, the vagueness is responsible for the deferral of the 'atmospheric result', for a surplus of the sum of the individual elements which has to be taken into account, especially if one is to study one of the summands. Vagueness is known primarily as a problem of language deriving from predicates, while structurally it plays a role in metaphysics, epistemology and the philosophy of language. It can thus cause problems in the field of aesthetics. It has been pushed out of the focus of attention by the ideal of precise language, which is particularly present in the sciences. Nonetheless, the occurrence of borderline cases, in which uncertainty arises regarding the applicability of a predicate, is not just characteristic of everyday language. When even a conceptual analysis is unable to determine the applicability of a predicate, a predicate is considered vague; it possesses a "predicative penumbra, in which neither truth nor falsehood clearly prevails. In other words, tertium datur" (Buldt, 2001, p. 531-532). The sentence 'The valley borders on the mountain' can serve as an example. It deals with two intelligible entities: valley and mountain. Where exactly, however, lies the border between the two? From which point is the mountain no longer a mountain, but already a valley? Such problems of delineation can also present themselves to a curator who is engaged in the atmosphere of his or her exhibition. Regarding the hanging of paintings, a curator may ask him- or herself: when does an exhibition become an exhibition? At what point is an exhibition furnished with sufficient atmosphere? Does atmosphere increase as more paintings are hung, such as in the so-called Petersburg style of hanging? Or is the atmosphere more agreeable when less wall space is claimed, as in the style of hanging that places clear emphasis on individual works?

5 Atmosphere is thus to be situated in this penumbra, in a conceptual or maybe ontological half-shadow, as an 'and' mediating between a subjective state and the qualities of one's surroundings, as a third term in the subject-object dichotomy pragmatically employed on an everyday basis. There are atmospheres that seem to adhere permanently to a given place. There are atmospheres that, in line with the classical concept of vagueness, are 'fickle', that appear 'restless' and unstable, that are 'vagabond'. The uncertainty concerning the unambiguous perceptibility of atmosphere, its gradual intensity or its feasibility makes atmosphere oscillate between 'whether' and 'whether not': its reception turns on the question of whether or not the assignment of a predicate to an atmosphere is appropriate, whether or not the perception of an atmosphere is dependent on one's own experiences - and if so, in what way - and whether or not an atmosphere is merely a subjective mood. Furthermore, the production of atmosphere turns on the question of whether or not certain objects generate atmosphere, whether or not atmosphere emerges from a specific constellation or setting in a room, and whether or not one can even manufacture a certain atmosphere with regard to a certain sensory quality. Now bringing the two concepts of 'atmosphere' and 'vagueness' together, I hope to be able to explain, or at least shed light on, the indeterminate discussion of atmospheres in everyday language as well as the uncertainty surrounding the creation of atmospheres.

6 In the context of everyday language, vagueness is ascribed to statements, situations, descriptions and perceptions that are uncertain or that lack clarity or definition. In the 
scientific or academic context, such phenomenal conditions, which formally appear lucid but whose content often leads to vague and metaphorical formulations, are neglected. That St. Petersburg's Hermitage boasts a fantastic atmosphere seems clear enough, but it can only be roughly outlined to which paintings, constellations of paintings or interior arrangements this atmosphere is attributable. Vagueness corresponds to a kind of uncertainty, tied up not only with the fear of terminological indeterminacy but also with the potential for a more conscious ambiguity. Vagueness is an unavoidable, but not always unwelcome, effect. This is because "fuzzy terms can be used more flexibly" (Schöne, 2011, p. 245), which is why a virtue is made out of necessity when it comes to describing and conveying atmospheres. In doing so, one is able not only to describe, but to summon a certain atmosphere. This also holds true for visual means of artistic expression, such as paintings, for if something is "very clear to see, it steers and restricts the viewer by stealing from the imagination the scope of play" (Ullrich, 2002, p. 18) $)^{5}$. It has been furthermore established in film studies that a lack of focus can seduce the viewer into becoming a part of the picture and fully immersed in it.

"The indeterminate attracts us with its secrets, which appear to lie within our grasp, but then evade definite capture. We quickly become emotionally involved. Thus it is a simultaneously distancing and inviting visuality. While focus is singular, something can be out of focus to varying degrees and shades. [...] Thus, the out-offocus stirs associations and is open to emotional reactions on the part of the viewer." (Smid, 2012, p. 147) ${ }^{6}$

\section{The Sorites Paradox}

Classically, vagueness has variously been illustrated by the sorites paradox ('sorós', Greek for 'heap'), or the paradox of the heap; indeed, vagueness has often been investigated in line with the sorites uncertainty (see Schöne, 2011). The sorites paradox is an example of how one's involvement can be a problem in terms of the relationship between a phenomenon and its description. Particularly from the perspective of artists of all "fields of aesthetic work" (Böhme, 1995, p. 35) ${ }^{7}$ who are determined to create reproducible atmospheres, the sorites paradox demonstrates how the treatment of material singularities (with an objective and subjective focus) systematically veils the turning point towards the qualitative moment of touching atmospheric situations in circumstances of composition and trial.

8 The sorites paradox draws our attention to three forms of vagueness which can help us to address different aspects of atmospheres in their vagueness, which is semantic, ontological as well as epistemic. Through the vagueness of atmosphere, we can better understand how imprecision can enter (scientific) descriptions, an imprecision from which, ultimately, the everyday, metaphorical, and poetic talk of atmospheres stems. This has methodological consequences that legitimize field studies with a scope of $n=1$.

9 Alongside its usage in everyday language, the terminological understanding of the concept of vagueness derives from a reengagement with the sorites paradox in the twentieth century and introduces a definition of vagueness as the presence of borderline cases resistant to inquiry. ${ }^{8}$ The sorites paradox allows us to see the boundaries of a concept as fluid. Take, for example, the concept of a 'heap of sand'. A large pile of sand is imagined. If one grain of sand is removed, what remains is still a pile, for if two piles of sand differ only in the absence of a single grain, they are both either piles or not piles. If one thus infers the rule that if $n$ grains of sand constitute a pile, $n-1$ grains do as well, one arrives at 
the paradoxical conclusion that any collection of sand grains is a pile, including the single grain that remains after all others have been removed. The absurdity also emerges at the other end of the spectrum: a droplet of water vapor does not yet constitute a cloud. If one were to add to this first droplet a second, one would still not have created a cloud. Thus, if $n$ droplets are not yet a cloud, neither are $n+1$ droplets, and, consequently, neither are billions of droplets. Yet there are clouds that consist of billions of droplets. How is it possible that concepts such as 'pile' or 'cloud', derived from the sorites paradox, are able to designate objects that are not clouds or piles? Clearly, there is a striking contradiction between the argument and its result, which is both counterintuitive and contraindicated. For the final grain of sand is indeed not a pile just as billions of droplets do in fact form a cloud. The sorites paradox appears to be a language game: it inevitably brings two seemingly similar linguistic concepts into conflict with each other. A multitude of droplets and a cloud appear to be incommensurable and lead to paradox when brought together and allowed to overlap in a sorites formulation.

Three ways to resolve this paradox come to mind: one could simply accept the argument's conclusion; one could hold the logic of argumentation to be fallacious and reject the conclusion; or one could modify or reject the premises?. If one were to accept the conclusion, vagueness critics could feel vindicated in their claim that vagueness contributes to the evaporation of concepts. The negative connotation attached to 'dissipation' in this sense is related to the descriptive operation of a vague concept such as 'cloud', which points dangerously in the direction of nihilism. The 'tertium datur' of vagueness refers, however, to vagueness's own characteristic logic, and to a pragmatic approach to a phenomenon that can be precisely named but only at the same time vaguely (see Baecker, 2005, p. 33). The associated softening of conceptual boundaries is a ' liquefaction' that, in contrast to 'dissipation', is to be understood more positively. Furthermore, the logic of argumentation cannot be rejected; because of the simplicity of argument and the few logical principles applied, it is better accepted in the form of polyvalent logics with graduated degrees of truth. Finally, the modification or rejection of the premises of the sorites paradox provides for the possibility of eliminating the form of vagueness at hand.

11 To sum up, the sorites paradox presents itself as an interplay between the intuitive plausibility of the individual steps in an argument and the absurdity resulting from a logical conclusion. It thus highlights the difficulty of delineating a boundary between two states that in fact flow into each other continuously and seamlessly. The underlying conditions by which the sorites argument proceeds are the iterative use of the modus ponens, in which no allowance is made for interruption or suspension; the tolerance principle, which permits small changes; and the binary or bivalence principle, which posits a binary framework of judgement involving true and false.

\section{The Forms of Vagueness}

12 The origins of vagueness can be traced to the relational triangle of world/language/self. Vagueness appears possible at every level and thus three forms can be distinguished from one another: semantic, ontological, and epistemic. These will form the points of reference below, allowing us to explore the concept and existence of atmosphere in terms of vagueness. 

term is designated vague if it has the quality of exhibiting imprecise boundaries or borderline cases in which it cannot be ascertained whether an object belongs to the class of objects that fall under said term. Vagueness points to sites of semantic incompleteness or insufficiency. Here, the standard claim is made that vagueness is a sign of conceptual dissipation as a result of poorly worked-out terms. The conceptual tolerance illustrated by the sorites paradox, in combination with the lack of conditions by which the operation of adding or subtracting can be interrupted, allows vague predicates to be treated differently semantically, according to their degree, from precise ones.

Ontological vagueness is vagueness as an element of the world and of reality. It is the property possessed by an object that makes it ambiguous, as a result of "a lack of clear spatial boundaries resulting from a vague partial belonging" (Buddensiek, 2006, p. 55) ${ }^{10}$. In terms of the example provided above - that of a mountain transitioning into a valley one is challenged: where does the valley begin and the mountain end? Apparently, one must assume that the boundary is fluid and that a transitional zone exists which is not yet entirely valley but which has ceased to be entirely mountain. However, this ontological vagueness contains a problem: a vague object is one for which one cannot delineate clear boundaries, but if one were to subtract successive parts of this object until all have been subtracted, one would eventually reach the point where there is no object at all. This would actually mark a fairly defined border. In order to avoid the supposition of a vague object, one can also cite an object's material independence from its concept and, rather, inquire into the semantic or epistemic form of vagueness. Still, that a mountain rises above a valley to a distinct height, while a valley spreads into a plain, suggests that a transition zone between mountain and valley exists.

Epistemic vagueness is vagueness in the sense of a deficiency of knowledge, in principle or in fact, regarding the object under discussion. One could assume that both vague and precise terms are semantically alike in that they establish clear boundaries. Even whole sentences built around vague terms are clearly either true or false. Ignorance, however, manifests itself as ambiguity regarding the assignment of truth values, arising, for example, from uncertainty concerning the full availability of all relevant information (see Buldt, 2001, p. 538; Sainsbury, 2001, p. 54; Wolski, 1980, p. 143). In the sense of epistemic vagueness, the sorites paradox provides evidence for the fact that at least one precondition of a vague statement is false. Because a droplet is not a cloud and because there must be a clear boundary between cloud and non-cloud, the rule 'If $n$ droplets do not yet constitute a cloud, then neither do $n+1$ droplets' must be in some way flawed. However, it is impossible, using a quantity of $n$, to precisely delineate the boundary. For when presented with a borderline case for a given vague term, we are left hopelessly ignorant. Thus, epistemic vagueness denotes that the terms are clear, while it problematizes the context in which knowledge is acquired, which already arises with the perceptions that the terms set out to describe. Humans are equipped with perceptual capacities that are unable to recognize sharp boundaries and hence must assume fuzziness and uncertainty (see Schöne, 2011, p. 174-189).

Given the three forms of vagueness, one should deliberate on which or how many forms of vagueness apply to atmosphere. What is more, one needs to distinguish between vagueness applying to the concept of atmosphere or atmosphere itself.

17 From the perspective of a practitioner, i.e. someone crafting material objects and constellations thereof, who - at least linguistically - feels obliged to differentiate between 
subject and object, one could argue that atmospheres are neither semantically nor ontologically but only epistemically vague. The problem of semantic vagueness is indeed fed by the relation between atmosphere, as a corporeal phenomenon, and the abstract concept of atmosphere. This does not, however, mean that the 'and' pinpointed in our definition of atmosphere - which mediates between subjective states and the qualities of settings - can be called vague. The definition focuses on that which comprises an atmosphere. It does so on a very general level, which causes the concept of atmosphere to spread outwards extensively. This is tied to the overdetermination of the definition of atmosphere: based in 'subjective states' and 'the qualities of a setting', the description of atmosphere generally refers to the concrete 'here and now', while as a phenomenon it is commonly understood as 'always and everywhere'. The question as to whether atmospheres are ontologically vague could be answered in the negative. For atmospheres - which only become objects of perception by mediating between one's particular state and the qualities of one's surroundings - one's involvement, one's being in the cloud, is of decisive importance. This affectedness could be brought up against the presence of ontological vagueness, in the sense that it could be held responsible for concealing the precise ontological boundary. Applied to the sorites paradox, this means that it is important that over the course of a repeated operation, again and again one ties the concept of 'pile' or 'cloud' to the outcome of this operation, even as, grain by grain or drop by drop, the ontological framework itself shifts. Because of one's involvement and in accordance with the tolerance principle mentioned earlier, the point at which this framework is no longer compatible with the premises of the sorites paradox cannot be pinned down. In the midst of one's involvement in incremental steps, the concept has become fluid, and one only realizes that something has gone awry when confronted with an absurd final result. The problem of one's involvement is closely tied to another: the lack of conditions determining when the operation is to be ceased. If, in the course of removing grains of sand, one were able to stop and reverse the last step, one could thus locate the boundary between pile and non-pile. The parallels between the perception and description of an atmosphere could be explained as follows: when one is involved in an atmosphere and attempts to describe it through a continuous enumeration of its particular elements, one cannot call the cumulative total of these perceptions an atmosphere. One would have only named the sum of individual impressions, which falls short of conveying the qualitative idiosyncrasy of an atmospheric whole. This also pertains to the processes of the production of atmosphere. Whether, for example, an exhibition is richly or sparsely organized, the point at which the atmosphere deriving from its particular character can be felt is determined by the coordination of the mood effects involved and the distanced usage of materials. Finally, the question as to whether atmospheres are epistemically vague can be answered in the positive. In a way analogous to St. Augustine's ruminations on the difficulties of explaining time, the experience of perception seems to allow speculation on the vagueness of atmospheres. Drawing on Augustine, if one speaks of atmospheres in an everyday context, then atmosphere appears to be a clear and well-defined term. However, if one attempts to explain the term atmosphere, its boundaries liquefy; the atmosphere appears vague and not susceptible to a comprehensible explanation. No clear perception of atmosphere seems to be tied to the clear definition of the term. The fact that the determining factor in the definition of atmosphere is an 'and' does indeed render it difficult to clearly name an atmosphere's subjective components versus its objective ones. This would be made easier by means of an 'or', which would quickly help to answer the question as to whether atmospheres are 
attributable only to the subject or only to the object. Nonetheless, the 'and' emphasizes precisely the 'in between' at the interface of subjective and objective. The 'and' allows for the understanding, suspended and latent, of which factors determine an atmosphere and to what extent. The 'and' thus supports the case that the vagueness of atmospheres is epistemic. However, because the perception of atmosphere, through one's being involved, is always filed under the pre-verbal category of "immediate sensation and physical feeling", atmosphere's reality can only be demonstrated retrospectively (Thibaud, 2003, p. 286) ${ }^{11}$.

Yet it is precisely the importance of involvement in an atmosphere which has the power to change the association of atmosphere with the three forms of vagueness. From the point of view of a theoretician who is concerned with the conceptualization of atmospheres according to the phenomena at hand, it is questionable whether atmospheres could not also be vague in a semantic or ontological sense. Given the semantic scope of the 'and' definition, one is tempted to ask: where is atmosphere, if it is everywhere? What is special about an atmosphere if it is applicable to all kinds of phenomena? The definition of atmosphere does not merely accept this situation as unavoidable; it receives it as part of the phenomenon. Additionally, semantic vagueness seems to be an integral part of everyday linguistic practice. Yet the fact that it is perceived as an unproblematic element in everyday language does not deny its very existence or, by contrast, underline the capacity of definitions to make it disappear. The question of ontological vagueness is closely tied to ontological conceptions of atmosphere. As a result, affectedness as an ontological condition of atmospheres, as a characteristic of the relation of one's state at a given time and the qualities of the surroundings, proves the atmosphere's ontological vagueness in the 'and' of it. Atmosphere becomes a concept conceptualizing vagueness in the world. Seen from these different angles, vagueness makes atmosphere non-categorical but at the same time accessible via discourse. It is vagueness that stands before the sum of one's subjective state and the qualities of one's setting like an uncertainty factor. It is thus to be emphasized that atmospheres are not to be found in a mere enumeration of perceptual components, but rather represent a surplus, one that is above all recognizable in the discovery of an atmosphere. As a classical paradigm of vagueness, the sorites paradox, with its formulaic structure, may indeed appear to present us with a process of enumeration or atomization. In the context of atmospheres, however, it precisely points to the problems generated by qualitative objects of perception. While enumeration functions quantitatively according to the model $1+1=2$ (as if only the sum counts, the many), the perception of atmosphere functions qualitatively according to the model 1 $+1=1$ (it is about quality, the quality of an atmosphere made up of single components). Atmosphere emerges as a "tempest of blurred islands," (Schmitz in Hahn, 2012, p. 72) (2) $^{12}$ an image that draws our attention to the liquefaction and fluidity of the phenomenon. Schmitz' definition provides similar support for our understanding of vagueness: "Feelings are spatial, but have no locus; they are poured-forth atmospheres" (Schmitz, 2009$, p. 23$)^{13}$. For - as is particularly the case in the social sciences - if one understands a 'locus' or site as a geometrically fixed point in space, and 'space' itself as a multiplicity of possible locations, then, through its opposition of 'space' and 'locus', a fluid, flowing indeterminacy is implied within this definition which is only rendered more pronounced by the choice of a term such as 'poured-forth'. 


\section{The Consequences}

19 Whether arising formally or phenomenally, the vagueness of atmosphere presents us with difficulties, particularly when sighted on safe terrain: as if among the clouds, contemporary art appears to have become ungraspable, nebulous, and vague as a result of its atmospheric character. In this way, it "no longer draws a distinction between art and life", the critical potential of the concept of atmosphere is a "pretty illusion", through which even "the felt 'sense' of atmospheric art-worlds [...] remains in the balance" (Assheuer, 2012) ${ }^{14}$. But perhaps such a critique acknowledges aesthetic phenomena merely as a means to an end while failing to recognize them as an end in themselves. The cloud was used above as an example for the sorites paradox, but it is also an illustrative metaphor for the difference between atmosphere as an object of perception and atmosphere as a perceptual stance. No two clouds are the same. However, their fuzzy peripheries do not yet indicate that they can be described as completely vague. Through our experience of clouds and the weather phenomena attached to them, we are able to categorize and characterize them; for example, whether they appear as a wispy ribbon on the distant horizon, colored red by a sunset, whether they hang low and heavy, or whether they roll along quickly or rain softly or torrentially. In order to sense the character of such moments, the object of perception and the perceiving subject must find themselves in the same place; they must be co-present in the 'and' of atmosphere. Thus, the product of this 'and' can become the content of perception. If one now schematically compares cloud and atmosphere, they become objects of perception when one views them from a distance and, despite fragmentation and disintegration, apprehends their particular effect. They become a perceptual stance when one finds oneself in the cloud, when one is endlessly enshrouded in it, when the cloud thus becomes the background to perception, shaping and helping to shape in its particular way the manner in which people and objects appear. To actively perceive an atmosphere is thus more a matter of being in the clouds than looking at them. To perceive an atmosphere at a distance is like viewing clouds.

Oliver Boberg makes use of the characterization of mood that thus becomes possible when he views "hundreds of photographs of real skies" in order to find out "which aspects of cloud formations are responsible for particular, recognizable moods. These are then sketched and, using various types of cotton wool and with the aid of light, perspex and artificial fog, they are modeled in the studio." (Boberg, 2007, p. 220) ${ }^{15}$ The cloud formations that he thus reproduces are then shown in diptychs or in series of up to ten individual photographs, all based on nearly the same, but each time slightly modified, composition. Boberg wants to seize and commit to recording something that is in permanent flux. The transitory nature of cloud formations is made clear, as well as the vagueness of atmospheres, which even under close scrutiny are able to veil the context of their production. However, the illusory nature of photographic reproduction is not the main focus of this work. Much more important is a concentration on the phenomenon. What do I perceive? How do I perceive it? Where am I? How do I feel? In the photographs of Berndnaut Smilde, perceptual contexts are brought together. In his Nimbus series, various clouds drift in interior spaces. Cloud and room are drawn into a Magrittesque interplay. Here, too, the photographer of clouds concentrates on the phenomenon and not on a pure aesthetic goal. The fact that clouds and atmospheres can be perceived and 
are tangible is placed at our disposal. Vagueness now stands as a touchstone of atmosphere discourse, initially in everyday language, but also semantically, ontologically, or epistemically. Can one ground comprehensive perception in clear concepts - and if so, how?

The entry of the topic of vagueness into the debate on atmosphere has positive consequences. The emphasis on vagueness is a corrective to a purely conceptual and formal unfolding of the discussion. To the benefit of faithfulness to the phenomenon, the theme of vagueness undermines a hasty exactitude. Because of one's involvement in atmospheric perception, the difference between the context of experience and that of description becomes clear. The atmosphere debate is thus formally enriched by a feel for unclear delineation and methodical uncertainties. It is also enriched in terms of content by a focus on the indeterminable nature of a perceptual situation. The everyday, at times poetic and metaphorical manner in which atmospheres are discussed becomes understandable through vagueness.

The ability to move between academic and poetic language allows one to gain a linguistic purchase on a given atmosphere. In contrast to the objective illumination of atmospheric situations, the "poetic explication preserves the situation to be explicated through a skillful frugality of expression, which, through a thin and tailor-woven veil [...] allows the intact fullness of the situation to shine through in all of its richness" (Schmitz, 2003, p. $264)^{16}$. Thus, the characters of vague atmospheres can be named and inter-subjectively negotiated. The character of an atmosphere "can, through the kind of enthralling description enabled by metaphorical language, leave an impression with more lasting resonance than would be the case with however precise an elaboration of details" (Hasse, 2012 , p. 25) ${ }^{17}$. In studying atmospheres, not only everyday language, but also poetic and metaphorical language can be used in collecting data and in analyzing the results of qualitative-empirical 'aisthetic' field research.

23 Aisthetic fieldwork is still a young method in the research on atmospheres. ${ }^{18}$ It attempts to feel for and tease out varying atmospheres that border on one another or flow into one another. Because empirical research on atmospheres is still in its infancy, aisthetic studies of this kind devote themselves primarily to the description of an atmosphere. Because of the difference between linguistic communication and the manner in which atmospheres are communicated, such descriptions constitute a necessary move into the medium of language. Aisthetic fieldwork is comprised of the following three components: the recording of all sense impressions, the expansion and supplementation of these perceptions using a mnemonic protocol, and the fact that the person collecting the data is the same as the person evaluating these data.

24 The noting down of all sense impressions as a means of preserving one's perceptions is a consciously chosen step. It allows access to an atmosphere as close and faithful as possible to the moment of perception. Of utmost importance is one's own physical presence at the locus of study, in the 'here and now' of the atmosphere under investigation. Without resorting to a potentially fallible memory, perceptions from within the sensory field or purview of an atmosphere are described, for often atmospheres, as a result of their vagueness, cannot be directly named. This description approximates an embracing of the holistic via the particular. Without regard to style or consistency, one commits to one's field notes individual sensory impressions and provisional descriptions that constitute the effect and resonance of a particular atmosphere. This effect (it may also be a linguistic one) is to be preserved in writing. In the process, however, one must avoid committing 
the error of the tourist by prioritizing a mediated access to a given atmosphere over one's own perceptual access, as in, for example, taking photographs in a museum rather than relying on one's ability to see.

Following the completion of these preliminary notes, one should then use the opportunity to weave into the field report amending and supplementary information drawn from a mnemonic protocol. It may be possible that one's research notes from the atmospheric field are difficult to comprehend, given the unique effect of an atmosphere at its locus. The filling out of these notes from memory allows new descriptions to flow into the report that may, in the sense of one's own involvement, be more distant or removed, but which emerge from presumably heightened consciousness of one's experience of the atmosphere. These supplementary descriptions thus constitute another methodological step preceding the evaluation of one's notes, allowing one to regard as a simultaneous perception individual aspects written successively. They reconstruct sense impressions with words and reflect on the conditions under which the atmosphere was perceived. Often, the amendments to the mnemonic protocol could be made in a language different from the one used for the notes in the field. Because of the temporal distance from the collection of data in the field, the language used is more reflective; in addition to adjectives and nouns, poetic expressions and neologisms are also used, which paraphrase the vague and carefully interweave it.

It is ultimately important to avoid discrepancies in one's use of vocabulary when evaluating one's notes. This is made possible by the fact that the person collecting the data and the person evaluating these data are one and the same, allowing the idiosyncrasies of individual usage to be compensated. The importance of certain notes will be highlighted. If the collection of data and the ensuing evaluation remain in the hands of one person, the researcher is freed from such questions as may arise regarding the relationship between subjectivity and objectivity in the notes, regarding the standardization of terms, or regarding a potential biased steering of the field notes in a certain direction. Thus freed, the researcher can more easily align his or her own descriptions regarding his or her individual state in light of the qualities of a particular setting - in other words, the prevailing atmosphere. In addition, the researcher is the person most qualified to connect the discursive context to the context of atmospheric perception. If individual sense impressions are recorded in the field notes, they can thus be illustrated and interpreted with an eye to the atmospheric whole.

This method of aisthetic fieldwork is based on the Parcours commenté as outlined by JeanPaul Thibaud and Grégoire Chelkoff. The Parcours commenté is a research technique in situ, i.e. by means of walking together and talking to each other in the field, it explores one's involvement in an atmosphere according to the principles "marcher, percevoir et décrire" (Thibaud, 2001, pp. 81-83). It centers on the following four steps: firstly, the 'observer'/observing, the acknowledgement of modes of perception and attitude in the field; secondly, the 'accompagner'/accompanying, the description while walking; thirdly, the 'evoquer'/evoking/reminiscing, the reactivating of sensual impressions; and, finally, fourthly, the 's'entretenir'/reviewing/conversing, the linguistic synchronizing of perception. As a result, the Parcours commenté is practically geared to the description of atmospheres (for instance in the urban context). Individual linguistic traditions and idiosyncrasies can be leveled out in a communicative way, and the need for communication caused by the vagueness of atmospheres can be satisfied by means of dialogue and commentary. For aisthetic fieldwork, the methodical synchronization of the 
observer and the observed is of key importance, as is the unity of the person collecting the data and the one assessing it. So it is a method that could be seen as a Parcours commenté exclusive to one person: the 'accompanying' of one's perceptions while taking notes, the reminiscing 'evoking', the 'conversing' with oneself, i.e. the reflection on and evaluation of the notes, are connected to only one language, the vocabulary of the researcher in the field, which should enable and augment the balancing of linguistic idiosyncrasies, an appropriate evaluation of one's own individual notes, and thus the appropriate reflection on said notes. The singular access provides the chance to approach and reflect on the pre-linguistic 'in-between' of the atmosphere in a particularly intense way, close to the perceptions made.

Aisthetic fieldwork is an open method that does not merely allow for variation, but in fact encourages it, with the aim of bringing about a further reflection on methods. In this form it is designed to pave the way for an empirical approach to the study of atmosphere that is suitable for and faithful to the phenomenon at hand. Here, the vagueness of atmospheres is not a stumbling block, but rather a milestone. A view of vagueness in the spirit of 'dissipation' could call for speechlessness in the face of the pre-linguistic nature of the atmosphere phenomenon. However, this contradicts the everyday (linguistic) treatment of atmospheres and absolves one of responsibility for serious efforts at utilizing the communicatory potential of atmosphere in aesthetic, (landscape) architectural, educational, critical, and other contexts. The work of art, which either formally or in terms of its content is involved in the creation of atmospheres, is unthinkable without the perceptual space in which it is embedded. It generates atmospheres and provides them with a commentary. In perception, one is in the clouds.

\section{BIBLIOGRAPHY}

Assheuer, Thomas. 2012. Wie auf Wolken. Die Kunst der Gegenwart wird atmosphärisch. Was soll das bedeuten? Die Zeit, 15.11.2012, No. 47. p. 61.

Baecker, Dirk. 2005. Atmosphäre als synthetisches Gestaltungsinstrument. In: Schmidt, Alexander; Jammers, Reinhard (eds.). Atmosphäre - Kommunikationsmedium der gebauten Umwelt. Essen: Red Dot Edition. p. 30-37.

Boberg, Oliver. 2007. Erinnerungen an Atmosphären. In: Goetz, Rainer; Graupner, Stefan (eds.). Atmosphäre(n). Interdisziplinäre Annäherungen an einen unscharfen Begriff. München: Kopaed. p. 211-222.

Böhme, Gernot. 1995. Atmosphäre. Essays zur Neuen Ästhetik. Frankfurt a.M.: Suhrkamp.

Buddensiek, Friedemann. 2006. Die Einheit des Individuums. Eine Studie zur Ontologie der Einzeldinge. Berlin: Walter de Gruyter.

Buldt, Bernd. 2001. Vagheit. In: Ritter, Joachim; Gründer, Karlfried \& Gabriel, Gottfried (eds.). Historisches Wörterbuch der Philosophie. Band 11: U-V. Basel: Schwabe. p. 531-540. 
Hahn, Achim (ed.). 2012. Erlebnislandschaft - Erlebnis Landschaft? Atmosphären im architektonischen Entwurf. Bielefeld: Transcript.

Hasse, Jürgen. 2012. Atmosphären der Stadt. Aufgespürte Räume. Berlin: Jovis.

Rauh, Andreas. 2012. Die besondere Atmosphäre. Ästhetische Feldforschungen. Bielefeld: Transcript.

Sainsbury, Richard. 2001. Paradoxien. Stuttgart: Reclam.

Schmitz, Hermann. 2003. Was ist Neue Phänomenologie? Rostock: Koch.

Schmitz, Hermann. 2009. Der Leib, der Raum und die Gefühle. Bielefeld: Edition Sirius.

Schmitz, Hermann. 2014. Atmosphären. Freiburg/München: Karl Alber.

Schöne, Tim. 2011. Was Vagheit ist. Paderborn: Mentis.

Smid, Tereza. 2012. Entgrenzte Stimmungsräume. Atmosphärische Funktionen filmischer

Unschärfe. In: Brunner, Philipp; Tröhler, Margrit \& Schweinitz, Jörg (eds.). Filmische Atmosphären.

Marburg: Schüren. p. 143-158.

Sorensen, Roy. 2006. Vagueness. In: Stanford Encyclopedia of Philosophy. Online: http://

plato.stanford.edu/entries/vagueness (consulted on February 10, 2010).

Thibaud, Jean-Paul. 2001. La méthode des parcours commentés. In: Grosjean, Michèle; Thibaud, Jean-Paul (eds.). L'espace urbain en méthodes. Marseille: Éditions Parenthèses. p. 79-99.

Thibaud, Jean-Paul. 2003. Die sinnliche Umwelt von Städten. Zum Verständnis urbaner Atmosphären. In: Hauskeller, Michael (ed.). Die Kunst der Wahrnehmung. Beiträge zu einer Philosophie der sinnlichen Erkenntnis. Zug: Die Graue Edition. p. 280-297.

Ullrich, Wolfgang. 2002. Die Geschichte der Unschärfe. Berlin: Wagenbach.

Weibel, Peter. 2012. Elektrosphären. In: Heibach, Christiane (ed.). Atmosphären. Dimensionen eines diffusen Phänomens. München: Fink. p. 155-172.

Williamson, Timothy. 2005. Vagueness. London: Routledge.

Wolski, Werner. 1980. Schlechtbestimmtheit und Vagheit - Tendenzen und Perspektiven.

Methodologische Untersuchungen zur Semantik. Tübingen: Niemeyer.

\section{NOTES}

1. See also the explanation by Weibel, 2012, p. 155-172.

2. To some extent, the text draws on my 2012 publication "Die besondere Atmosphäre. Ästhetische Feldforschungen" ["The Special Atmosphere. Aesthetic Investigations in the Field"]. It also contains original contextualizations, examples and a more elaborate approach to forms of vagueness.

3. My translation of the original text: "Beziehung von Umgebungsqualitäten und menschlichem Befinden. Dieses Und, dieses zwischen beidem, dasjenige, wodurch Umgebungsqualitäten und Befinden aufeinander bezogen sind, das sind die Atmosphären".

4. My translation of the original text: "prädikativen Halbschatten (,penumbra), in dem weder Wahrheit noch Falschheit eindeutig regieren: Tertium datur." On the tripartite nature of the zone of reference specific to a given concept or term, consisting of clearly positive and clearly negative instances in which the term is applied, alongside a penumbra, see also Russell, cited in Wolski, 1980, p. 87. 
5. My translation of the original text: “...scharf zu sehen ist, bedrängt den Wahrnehmenden und engt ihn ein, da es der Fantasie jeden Spielraum nimmt."

6. My translation of the original text: "Das Unbestimmte reizt uns mit seinem Geheimnis, das scheinbar in Griffnähe liegt und sich doch dem definitiven Zugriff entzieht. Wir sind emotional schnell involviert. Es handelt sich also um eine gleichzeitig distanzierende und einladende Visualität. Während Schärfe einzigartig ist, existiert die Unschärfe in vielen Abstufungen und Schattierungen. [...] Dadurch weckt sie Assoziationen und öffnet sich gegenüber emotionalen Reaktionen seitens der Betrachter."

7. My translation of the original text: "Sparten ästhetischer Arbeit."

8. See Buldt, 2001, p. 531; also Sorensen, 2006: "Vagueness is standardly defined as the possession of borderline cases. [...] Borderline cases are inquiry resistant." On the sorites paradox generally, see also Sainsbury, 2001, p. 41 and Williamson, 2005, p. 8-25.

9. For a more thorough treatment of the three possibilities named here, see Sainsbury, 2001, p. 51 and Rauh, 2012, p. 183.

10. My translation of the original text: “...aufgrund fehlender eindeutiger räumlicher Grenzen infolge vager Teilzugehörigkeit."

11. My translation of the original text: "Bereich der unmittelbaren Empfindung und leiblichen Regung ."

12. My translation of the original text: "Gewoge verschwommener Inseln."

13. My translation of the original text: "Gefühle sind räumlich, aber ortlos, ergossene Atmosphären."

14. My translation of the original text: "...keinen Unterschied mehr zwischen Kunst und Leben; schöne Illusion; der gefühlte ,Sinn' der atmosphärischen Kunst-Welten [...] in der Schwebe."

15. My translation of the original text: "Hunderte von Fotografien von realen Himmelssituationen; welche Komponenten von Wolkenformationen für eine bestimmte, wiedererkennbare Stimmung verantwortlich sind. Diese [werden] wiederum durch Skizzen fixiert und im Atelier mittels verschiedenster Sorten von Watte und unter Zuhilfenahme von Licht, Plexiglas und Kunstnebel in einer Art Modellsituation inszeniert."

16. My translation of the original text: “...schont die poetische Explikation die zu explizierende Situation durch geschickte Sparsamkeit der Rede, die hinter einem dünnen, aber passend und treffend gewebten Schleier [...] die ungebrochene Ganzheit der Situation mit der binnendiffusen Fülle ihrer Bedeutsamkeit durchscheinen lässt."

17. My translation of the original text: “...drängt sich in der packenden Beschreibung dank der metaphernhaften Rede nachhaltiger auf, als er in noch so detaillierter Genauigkeit von Einzelheiten hätte dargelegt werden können."

18. For more details see Rauh, 2012, p. 203.

\section{ABSTRACTS}

To define 'atmospheres' as phenomena between object and subject in the process of perception has almost generally been accepted. Atmospheres are experienced in terms of affect as quasiobjective, free-floating emotions. Given that, how may an atmosphere be described adequately? In the course of listing the multiple characteristics of atmosphere, problems that have to do with language emerge. By juxtaposing the order of language and the order of perception, the vagueness of atmospheres becomes visible - as the sorites paradox (accumulation) shows. Yet descriptions of atmospheres do not have to be vague; they can evoke different characters of 
atmospheres. The issue of vagueness is discussed from a semantic, ontological and an epistemic perspective. Atmospheres can be made tangible by means of the qualitative-empirical method of 'aesthetic fieldwork'. This method stresses three methodological aspects as a consequence of the vagueness of atmospheres. It is based on the Parcours commenté and entails a subjectconcentrated approach to atmospheres in order to avoid the traps of the forms of vagueness.

La définition des ambiances comme phénomène entre le sujet et l'objet dans le processus de la perception peut être considérée comme établie. Les ambiances sont éprouvées de manière affective comme des objets-sentiments dans l'espace environnant. Si tel est le cas, il convient alors de se demander comment décrire ces ambiances d'une manière adéquate. Quand on établit la liste des caractéristiques requises, des problèmes liés au langage apparaissent: dans l'affrontement entre l'ordre du langage et celui de la perception, le vague des ambiances apparaît comme le montre les paradoxes sorites (paradoxes de l'accumulation). Pourtant les descriptions d'ambiances ne sont pas seulement vagues mais aussi capables d'évoquer différents caractères de ces dernières. Le problème du vague sera abordé d'un point de vue sémantique, ontologique et épistémologique. Grâce à la méthode qualitative-empirique de l'analyse scientifique du champ esthétique, les ambiances peuvent être décrites plus précisément. Cette méthode souligne trois aspects primordiaux comme conséquences du "vague des ambiances". Elle se base sur le processus du parcours commenté et développe une approche des ambiances très centrée sur le sujet pour éviter les pièges des formes du vague.

\section{INDEX}

Mots-clés: vague, paradoxe, épistémologie, méthode qualitative

Keywords: vagueness, paradox, epistemology, qualitative method

\section{AUTHOR}

\section{ANDREAS RAUH}

Dr. Andreas Rauh is managing director of the Human Dynamics Centre (HDC) of the faculty of humanities at the University of Würzburg (www.hdc.uni-wuerzburg.de). He studied philosophy, education theory and art education. Since 2008, he has been a member of the International Ambiances Network and he is an associate member of the Atmospheric Spaces Network. More information: www.andreasrauh.eu

Contact: andreas.rauh@uni-wuerzburg.de 